\title{
Transnational Professional Relations in the Long Twentieth
}

\section{Century ${ }^{1}$}

\section{Christoph Laucht (Swansea University)}

Professions and professionalization are widely regarded by cultural and social historians as key markers of the modernization process. As Harold Perkin, the founder of the Social History Society, argued: 'The twentieth is not [...] the century of the common man but of the uncommon and increasingly professional expert'. ${ }^{2}$ Many studies of professionalization have so far analysed processes in which professions were established and transformed in the context of individual nation-states or through a comparative lens. ${ }^{3}$ Simultaneously, transnational approaches have broadened the empirical terrain within historical studies and have begun to initiate a profound reconceptualization of national and international histories, underlining the significance of transnational relations across national boundaries. ${ }^{4}$ Yet, these two historiographical strands - professions and professionalization on the one hand and transnational frameworks on the other - have largely been treated in isolation from each other.

This special issue thus combines these two fields of enquiry to explore relations between professionals and professions in a transnational context. In particular, the contributions in the present volume seek to explore how and to what effect professionals and their professional practices have transcended national boundaries as well as to assess the significance of transnational experiences and connections for the fashioning of professional identities and practices. Through a series of case studies, this volume aims to foster a better understanding of the crucial role that cross-border exchanges have played in the establishment of professions, the diffusion of professional practices and the promotion of professionalization. By placing professions within their wider transnational contexts, the contributors gathered here 
seek to demonstrate the significant impact of such cross-border encounters on the formation of nationally constituted professions.

Conceptually, contributors follow Joseph Nye's and Robert Keohane's pioneering definition of "transnational interactions" as "the movement of tangible and intangible items across state boundaries when at least one actor is not an agent of a government or an intergovernmental organization'. ${ }^{5}$ Moreover, 'professions' refer here not only to traditional white-collar occupations such as lawyers, engineers or medical professionals but, in a more inclusive fashion, also to social workers or employees in the hotel or forestry sectors, thereby focusing on their skills as a chief marker of professionalization. ${ }^{6}$ By considering vocational training and social work, this special issue also seeks to inspire a further de-hierarchization away from white-collar professions within the study of transnational professional relation. Here, future research could converge with a renewed interest in labour history, for example. ${ }^{7}$ Finally, 'relations' represent, as Pierre-Yves Saunier argues elsewhere, the result of '[c]onnections and circulations [...] between different entities and participants brought together by flows and ties'. As such, they 'are the effect or relevance these entities have on and for one another'. 8

The articles in this special issue explore transnational professional relations in the long twentieth century. On one level, purely pragmatic reasons dictate the use of this timeframe; for two of the contributions (Payen-Variéras and Bertelsen) address transnational professional relations around the verge of the nineteenth and twentieth centuries. But, on a broader conceptual level, such a longue durée approach is also useful because it allows for the consideration of diachronic developments and contexts relevant to any particular episode of transnational professional relations in the twentieth century. Ondřej Matějka impressively demonstrates this in his study of the modified uses of transnational social capital by Czech pastors in the Cold War. ${ }^{9}$ Here, future research into transnational professional relations could 
push back further in time beyond the distinctly modern timeframe of this special issue. ${ }^{10}$ Likewise, future work on this topic could build on the geographical foci of some of the essays (Bray, Wagner and Bertelsen) in the special essay and continue to move further away from the prevailing emphasis on Europe and North America in the existing historiography of professions and professionalization. ${ }^{11}$

\section{Towards an Analytical Framework}

To stimulate further research into the subject matter and to link the contributions in the present volume in a coherent manner, this introductory essay proposes an outline for an analytical framework comprising a preliminary set of five - often inter-related - foundational pillars. ${ }^{12}$ The case studies of transnational professional relations assembled in this special issue commonly rest upon one or more of these columns, with varying intensity. More generally, the first one of these foundational layers concerns the interplay between professionalization, modernization and transnationalism, including the wider economic and social order in which transnational professional actors operate. $^{13}$ After all, the professionalization and institutionalization of specific professions provided key prerequisites to enable the formation of transnational professional relations, as the articles by Payen-Variéras and Sanz Roig clearly demonstrate. ${ }^{14}$ Within transnational professional relations, professionalization and institutionalization processes range from the evolution and transfer of specific sets of skills amongst the members of a specific profession to transnational recruitment. ${ }^{15}$

Besides the wider contexts of professionalization, transnationalism and modernization, the social and cultural construction of professional identity represents a second chief beam in the foundations of the proposed analytical framework. On a fundamental level, any attempt to examine identity - professional or other - needs to engage with the analytical categories of class, gender and ethnicity. ${ }^{16}$ At the same time, specific expertise, along with certain codes of practice, ethos or etiquette mark an integral component in professional identity formation. ${ }^{17}$ In 
this context, Harold Perkin's notion of 'professional elites' is of great significance. ${ }^{18}$ After all, expertise came to represent an increasingly important feature of professional identity. This did not only apply to professionals engaging in transnational relations but to members of these 'professional elites' who also became increasingly involved in the work of non-government organizations (NGOs) or in 'transnational professional activism' against such issues as nuclear war. ${ }^{19}$

Central to the role of expertise in professional identity formation is the production of specialist knowledge in a subject area relevant to a particular profession. While professionals often engaged in transnational relations through transnational networks that addressed international or global issues, they often followed a 'glocalized' agenda and drew on locally created knowledge. ${ }^{20}$ As a result, local, regional or national issues never entirely vanished from the programmatic outlook of many participants in transnational professional relations - or 'national internationalists', as Holger Nehring calls such historical actors who look at international issues from a national perspective. ${ }^{21}$ In the present volume, Thomas Bray locates his analysis of postwar British social work not only within European but postcolonial contexts. Similarly, Larissa Wagner stresses the role that both state and non-state actors in the West German state of Bavaria played in development aid.

If specialist knowledge provided the basis for professional expertise, it also earned professionals trust - both from state and non-state actors, including the general public. ${ }^{22}$ Ultimately, expertise and trust thus empowered professionals. ${ }^{23}$ And power is not only a significant feature in the engagement of professional experts with non-experts but in transnational relations between professionals generally. As such, power (or influence) marks a third key plank of transnational professional relations. Asymmetry is a fundamental characteristic of professional relations - both within and across the borders of nation-states. ${ }^{24}$ It has received particular attention by scholars studying transnational encounters as through a 
feminist or global history lens, for example. ${ }^{25}$ Alongside asymmetry, power manifests itself in different forms in transnational professional relations. Even transnationalism itself can become a major asset for professionals, as all the contributions in this special issue demonstrate to some degree. In a similar fashion, influence in transnational professional relations can rely upon social capital, as Payen-Variéras and Matějka show in their contributions.

Simultaneously, the question of power reveals a tension between seemingly objective professional experts who supposedly speak with the voice of factual authority and a politicization of their work, as research into NGOs and 'transnational professional activism' has revealed. ${ }^{26}$ Such 'progressive professionals', as Christopher Moores terms them, often placed themselves 'between the formal tactics of an insider pressure group and the more informal tactics of social movements'. ${ }^{27}$ This was also the case in transnational professional relations; for the involvement of expert professionals in informal transnational networks such as the Pugwash Conferences on Science and World Affairs (PCSWA) or International Physicians for the Prevention of Nuclear War (IPPNW), which commonly engaged with state actors, exposed this tension and ambivalence. ${ }^{28}$ Other forms of politicization concerned the delicate issue of implementing a returnee programme for trainees from 'developing nations' who had completed their vocational training in Bavaria or the engagement of Czech Protestant pastors with the Communist regime in Czechoslovakia, as Wagner and Matějka respectively demonstrate in their articles.

While transnational networks formed an integral component of power in transnational professional relations, they also represented important fora for transnational communication between professionals. This fourth aspect of transnational professional relations - the means through which professionals communicate transnationally - comprises various forms of communication and types of exchanges. Apart from transnational networks, they include language - discourse, code and jargon - or the transmission of ideas via different technological 
means (e.g. telegraph, telephone, internet or social media). And all contributions in this special issue deal with transnational communication in one form or another. Work on 'transnational societal spaces' (Ludger Pries) and “"intermediary organizations”" (Dominik Lachenmeier) as well as the spatial dimensions within transnational history more widely has also provided further conceptual bearings to examine the roles of international conferences, organizations or professional training facilities as sites of transnational communication and exchanges amongst professionals. Two articles (Bray and Wagner) in this volume specifically address the spatial dimensions of transnational professional relations. ${ }^{29}$

Transnational communication and encounters, as per "“intermediary organizations",' can produce different outcomes. And the final pillar of this analytical framework thus concerns the effects of transnational professional relations. Although all contributions in this special issue deal with transnational professional relations that produced clear outcomes, it is important to stress that it can be difficult at times - not to say virtually impossible - to gauge the exact impact of transnational professional relations. Similarly, not all transnational encounters between professionals necessarily lead to changes in professional practices or influence professionalization processes. ${ }^{30}$ Yet, these ostensibly unproductive encounters could still prove useful in the sense that participants might draw lessons from them for future involvement in transnational relations. At the same time, non-human actors like germs can prompt moves towards professionalization as in the case of a specialization in bacteriology, for instance..$^{31} \mathrm{In}$ this special issue, two articles (Bertelsen and Matejka) focus more specifically on the consequences of transnational professional relations.

\section{The Contributions in this Volume}

This volume brings together an international team of scholars from different academic disciplines, including, apart from social, cultural and economic history, international relations and literary studies, to investigate transnational professional relations from the late 19th century 
onwards through a set of case studies of individual and collective actors from different professions. Its aim is to contribute to a conceptualization of transnational professional relations and explore their analytical potential for a more complex understanding of transnationalism in modern history. The six contributions are organized thematically into three blocks that each focus predominantly (but not exclusively) on one facet of the analytical framework proposed in the preceding section.

The first section explores professionalization processes. It opens with Evelyne PayenVariéras' examination of British accountants in the United States in the late nineteenth and early twentieth centuries. In her analysis, she demonstrates the ways in which British accountants brought with them specific British accounting practices, as a form of social capital that she defines 'both as intellectual skills and as a set of connections with a peculiar community', to the United States and how this exchange affected accounting in the United States. Payen-Variéras does not consider social capital in terms of its 'status-enhancement functions' but 'as a set of flexible resources which social actors did not only move across borders, but also adjusted to their career plans and professional opportunities'.

Diana Sanz Roig's study 'Specialization and Institutionalization: The Transnational Professionalization of European Literary Criticism during the Interwar Period' then completes this first part. By looking at transnational connections of literary critics and magazines in the period between the end of the First and the beginning of the Second World War, Sanz Roig examines three dominant areas where the specialization and institutionalization of European literary criticism took place at that time. Besides the role of literary critics and magazines in transnational networks, the piece examines the creation of institutionalized inter-cultural networks and the relationship between the professionalization of literary criticism and modernity more broadly. 
The subsequent two essays by Thomas Bray and Larissa Wagner focus on sites of transnational encounters and exchanges between professionals. In his article 'Global Solutions and Local Needs: Transnational Exchanges in Post-war British Social Work', Thomas Bray thus demonstrates the ways in which the International Conference of Social Work helped social workers foster 'a professional image of social work and its contribution to democratic society'. Importantly, his transnational contextualization of British social work extends to immigrant social workers.

If Bray looked in part at immigration as a contributory factor to transnational professional relations, the same applies to Larissa Wagner. Her contribution deals with Bavaria as a site where state and non-state actors cooperated in delivering vocational training programmes as part of West German development aid to nations in the so-called 'Third World'. Trainees in these programmes acquired specific skills in areas such as the hotel or forestry sectors. Wagner's article reveals the different contexts that can motivate different actors to engage in transnational professional relations. In particular, she emphasizes two further motivations beyond vocational training. While the West German government viewed development aid as a weapon in the Cold War to fight its antagonist, East Germany, both the Bavarian state government and private businesses sought to use vocational training as a means to forge trade links with the trainees' home countries.

A final part concludes the volume with two articles that examine the legacies of transnational professional relations, in particular the role of transnational intellectual relations and education therein, more specifically. Combining approaches from historical studies and international relations, Rasmus Gjedssø Bertelsen looks at French and American missionary universities in the Middle and Far East in order to examine the roles of Protestant and Catholic missionary intellectuals in higher education. Bertelsen's essay 'seeks to contribute to understanding the role of universities as transnational actors between Eastern and Western 
societies and the extent and limitations of their soft power in societies in the East and the West'. The article shows that many of the French and American universities set up in China, Egypt and other nations around the turn of the nineteenth and twentieth centuries have since provided long-lasting legacies and continue to influence tertiary education in East Asia and the Middle East.

The final article in this section (and special issue) also has a religious theme: Ondřej Matějka examines the ways in which Czech Protestant pastors adapted the uses of transnational social capital, namely contacts in Western Europe, that they had previously acquired through transnational networks in the face of major political changes from the 1940s to the 1960s. If these members of the clergy had established professional links with colleagues and professional organizations in Western European nations through long-established networks since the second half of the nineteenth century, the creation of the Communist dictatorship in Czechoslovakia after the Second World War now forced them to modify the uses of their 'unique connections' to maintain links across the East-West divide. In this, Matějka not only demonstrates, once more, the usefulness of a longue durée approach but reveals the extent to which changing political contexts can prompt a re-assessment and a re-appropriation of the uses of such transnational social capital. While the contributions gathered in this special issue can only offer a glimpse into specific aspects of the social and cultural histories of transnational professional relations, they will hopefully stimulate further research into this important subject matter.

1 The author wishes to thank Ian Gwinn and Stephan Petzold for co-organizing the 'Transnational Professional Relations in the Twentieth Century' workshop at the University of Leeds, UK, in 2013, out of which this special issue evolved. Initially, Stephan Petzold also made some conceptual contributions to the present volume. Further thanks are due to the Economic History Society and Leeds University, especially the School of History and the Leeds Humanities Research Institute Pump-Priming Fund, for financial and organizational support for this international workshop. Finally, Malcolm Chase's encouragement and enthusiasm made this volume possible.

${ }^{2}$ Harold Perkin, The Rise of Professional Society: England since 1880 (1989; London: Routledge, 2002), p. 2. 
${ }^{3}$ See, for example: Konrad H. Jarausch, The Unfree Professions: German Lawyers, Teachers, and Engineers, 1900-1950 (New York: Oxford University Press, 1990); Sean F. Johnston, The Neutron's Children: Nuclear Engineers and the Shaping of Identity (Oxford: Oxford University Press, 2012); Maria Malatesta, Professional Men, Professional Women: The European Professions from the 19th Century to Today (London: Sage, 2011); Maria Malatesta, ed., Society and the Professions in Italy, 1860-1914 (Cambridge: Cambridge University Press, 1995); Harold Perkin, The Third Revolution: Professional Elites in the Modern World (London: Routledge, 1996); Jörg Requate, Journalismus als Beruf: Entstehung und Entwicklung des Journalismusberufs im 19. Jahrhundert. Deutschland im internationalen Vergleich (Göttingen: Vandenhoeck and Rupprecht, 1995); Hans-Ulrich Wehler, ed., Professionalisierung in historischer Perspektive, spec. issue of Geschichte und Gesellschaft, 6. 3 (1980); Harold L. Wilensky, 'The Professionalization of Everyone?', American Journal of Sociology, 70. 2 (1964), 137-58.

4 See, for example: Patricia Clavin, 'Defining Transnationalism', Contemporary European History, 14.4 (2005), 421-39; Laura Briggs, Gladys McCormick and J.T. Way, 'Transnationalism: A Category of Analysis', American Quarterly, 60.3 (2008), 625-48; Erik van der Vleuten, 'Toward a Transnational History of Technology: Meanings, Promises, Pitfalls', Technology and Culture, 49.4 (2008), 974-94; Simone Turchetti, Néstor Herran and Soraya Boudia, eds., Transnational History of Science, spec. issue of the British Journal for the History of Science, 45.3 (2012); Pierre-Yves Saunier, Transnational History (Basingstoke: Palgrave Macmillan, 2013); Fiona Paisley and Pamela Scully, Writing Transnational History (London: Bloomsbury Academic, 2019). Furthermore, the fact that Palgrave Macmillan issued a specific dictionary of transnational history demonstrates the extent to which this field has become established: Akira Iriye and Pierre-Yves Saunier (eds), The Palgrave Dictionary of Transnational History: From the Mid-19th Century to the Present Day (Basingstoke: Palgrave Macmillan, 2009). For a critical review of this reference book, see Ann-Christina L. Knudsen and Karen Gram-Skjoldager, 'Historiography and Narration in Transnational History', Journal of Global History, 9. 1 (2014), 143-61. On the development of transnational history within a specific national context, see: Petra Goedde, 'Power, Culture, and the Rise of Transnational History in the United States', International History Review, 40.3 (2018), 592-608

5 Joseph Nye and Robert Keohane, 'Transnational Relations and World Politics: An Introduction', International Organization, 25.3 (1971), 329-49 (p. 332).

${ }^{6}$ On skills: Kathleen Thelen, How Institutions Evolve: The Political Economy of Skills in Germany, Britain, the United States, and Japan (Cambridge: Cambridge University Press, 2004); Lutz Raphael, 'Knowledge, Skills, Craft? The Skilled Worker in West German Industry and the Resilience of Vocational Training, 1970-2000', German History, 37.3 (2019), 359-73. 7 See, in particular: Stefan Berger, ed., German Labour History, special issue of German History, 37.3 (2019).

${ }^{8}$ Saunier, Transnational History, p. 80.

${ }^{9}$ For a classic approach to the 'long twentieth century', see Giovanni Arrighi, The Long Twentieth Century: Money, Power, and the Origins of Our Times, new and updated edn (London: Verso, 2010).

${ }^{10}$ For a study of pre-modern professionalization, see: James A. Brundage, The Medieval Origins of the Legal Profession: Canonists, Civilians, and Courts (Chicago: University of Chicago Press, 2008).

${ }^{11}$ Studies with such a strong Western orientation include: Jarausch, The Unfree Professions; Johnston, The Neutron's Children; Perkin, The Rise of Professional Society; Requate, Journalismus als Beruf; Malatesta, Professional Men, Professional Women; Malatesta, ed., Society and the Professions in Italy. By contrast, future research into non-Western contexts of transnational professional relations could draw inspiration from the historiography of the 
'Global Cold War' and the engagement of Western nations with the so-called Third World. See, for example: Odd Arne Westad, The Global Cold War: Third World Interventions and the Making of Our Times (Cambridge: Cambridge University Press, 2005); Quinn Slobodian, Foreign Front: Third World Politics in Sixties West Germany (Durham: Duke University Press, 2012); Young-Sun Hong, Cold War Germany, the Third World, and the Global Humanitarian Regime (Cambridge: Cambridge University Press, 2015); Anne Maud Bracke and James Mark, eds, Between Decolonization and the Cold War: Transnational Activism and Its Limits in Europe, 1950s-90s, spec. issue of Journal of Contemporary History, 50.3 (2015).

${ }^{12}$ Since this framework is designed for transnational professional relations, it is, by no means, as substantial as the one outlined by Saunier for transnational history more generally. See: Saunier, Transnational History.

${ }^{13}$ Here, work on transnationalism and technological innovation provides a good example. See, for example: Thomas J. Misa and Johan Schot, eds., Inventing Europe: Technology and the Hidden Integration of Europe, spec. issue of History and Technology, 21. 1 (2005); Erik van der Vleuten and Anne Kaijser, eds, Networking Europe: Transnational Infrastructures and the Shaping of Europe, 1850-2000 (Sagamore Beach, MA: Science History Publications, 2006); Martin Kohlrausch (ed.), Technological Innovation and Transnational Networks: Europe between the Wars, spec. issue of Journal of Modern European History, 6. 2 (2008); Martin Kohlrausch and Helmuth Trischler, Building Europe on Expertise: Innovators, Organizers, Networkers (Basingstoke: Palgrave Macmillan, 2014).

${ }^{14}$ For examples of this, see: Peter Lambert, 'The Professionalization and Institutionalization of History', in Writing History: Theory and Practice, ed. by Stefan Berger, Heiko Feldner and Kevin Passmore, 2nd edn, (London: Bloomsbury, 2010), pp. 40-58; Paul Starr, The Social Transformation of American Medicine (New York: Basic Books, 1982); Esa Konttinen, 'Professionalization as Status Adoption: The Nobility, the Bureaucracy, and the Modernization of the Legal Profession in Finland', Law and Social Inquiry, 13. 3 (1991), 497-526; W. Wesley Pue, Lawyers' Empire: Legal Professions and Cultural Authority, 1780-1950 (Vancouver, BC: University of British Columbia Press, 2016).

${ }^{15}$ On skills: Thelen, How Institutions Evolve. On recruitment: Nir Arielli and Bruce Collins, eds, Transnational Soldiers: Foreign Military Enlistment in the Modern Era (Basingstoke: Palgrave Macmillan, 2013).

${ }^{16}$ Kees van der Pijl, Transnational Classes and International Relations (London: Routledge, 1998); Roland Erne et al., 'Introduction: Politicizing the Transnational', Labor History, 56. 3 (2015), 237-45; Malatesta, Professional Men, Professional Women, pp. 126-63; Eve Rosenhaft and Robbie Aitken (eds), Africa in Europe: Studies in Transnational Practice in the Long Twentieth Century (Liverpool: Liverpool University Press, 2013).

${ }^{17}$ See the work on engineers: Johnston, The Neutron's Children; Elisabeth van Meer, 'The Transatlantic Pursuit of a World Engineering Federation: For the Profession, the Nation, and International Peace, 1918-48', Technology and Culture, 53. 1 (2012), 120-45; Gary Lee Downey and Juan C. Lucena, 'Knowledge and Professional Identity in Engineering: CodeSwitching and the Metrics of Progress', History and Technology, 20.4 (2004), 393-420.

${ }^{18}$ Perkin, The Third Revolution.

${ }^{19}$ On NGOs: Matthew Hilton, James McKay, Nicholas Crowson and Jean-François Mouhout, Politics of Expertise: How NGOs Shaped Modern Britain (Oxford: Oxford University Press, 2013), pp. 54-79; Matthew Hilton, Nick Crawson, Jean-François Mouhot and James McKay, eds., Historical Guide to NGOs in Britain: Charities, Civil Society and the Voluntary Sector since 1945 (Basingstoke: Palgrave Macmillan, 2012); Nick Crawson, Matthew Hilton and James McKay, eds., NGOs in Contemporary Britain: Non-State Actors in Society and Politics since 1945 (Basingstoke: Palgrave Macmillan, 2009). On 'transnational professional activism': 
Christoph Laucht, 'Transnational Professional Activism and the Prevention of Nuclear War in Britain', Journal of Social History, 52. 2 (2018), 439-67 (pp. 439-440).

${ }^{20}$ On the role of transnational networks in spreading locally manufactured knowledge globally: Simone Turchetti, Néstor Herran and Soraya Boudia, 'Introduction: Have We Ever Been "Transnational"? Towards a History of Science across and beyond Borders', British Journal for the History of Science, 45. 3 (2012), 319-36 (p. 331). On 'glocalization': Victor Roudometof, Glocalization: A Critical Introduction (London: Routledge, 2016).

${ }^{21}$ Holger Nehring, 'National Internationalists: British and West German Protests against Nuclear Weapons, the Politics of Transnational Communications and the Social History of the Cold War, 1957-1964', Contemporary European History, 14.4 (2005), 559-82.

${ }^{22}$ Albrecht Weisker, 'Expertenvertrauen gegen Zukunftsangst: Zur Risikowahrnehmung der Kernenergie', in Vertrauen: Historische Annäherungen, ed. by Ute Frevert (Göttingen: Vandenhoeck \& Rupprecht, 2003), pp. 394-421.

${ }^{23}$ Ute Frevert, Vertrauensfragen: Eine Obsession der Moderne (Munich: C.H. Beck, 2013), pp. 215-20; Nico Stehr and Reiner Grundmann, Experts: The Knowledge and Power of Expertise (London: Routledge, 2011).

${ }^{24}$ Saunier, Transnational History, p. 87. On the 'national' vs. 'transnational': Brenda Yeoh and Katie Willis, eds., State/Nation/Transnation: Perspectives on Transnationalism in the Asia-Pacific (London: Routledge, 2004).

25 See, for example: Inderpal Grewal and Caren Kaplan, eds., Scattered Hegemonies: Postmodernity and Transnational Feminist Practices (Minneapolis: University of Minnesota Press, 1994); Matthew Hilton and Rana Mitter, eds., Transnationalism and Contemporary Global History (Oxford: Oxford University Press, 2013).

26 Hilton, McKay, Crowson and Mouhout, Politics of Expertise, pp. 108-187; Laucht, 'Transnational Professional Activism and the Prevention of Nuclear War in Britain', pp. 443444.

27 Christopher Moores, 'The Progressive Professionals: The National Council for Civil Liberties and the Politics of Activism in the 1960s', Twentieth Century British History, 20.4 (2009), 538-60 (p. 539).

${ }^{28}$ Matthew Evangelista, Unarmed Forces: The Transnational Movement to End the Cold War (Ithaca, 1999); Claudia Kemper, Medizin gegen den Kalten Krieg: Ärzte in der anti-atomaren Friedensbewegung der 1980er Jahre (Göttingen, 2016); Alison Kraft, Holger Nehring and Carola Sachse, eds., The Pugwash Conferences and the Global Cold War: Scientists, Transnational Networks, and the Complexity of Nuclear History, spec. issue of Journal of Cold War Studies, 20. 1 (2018).

${ }^{29}$ On 'transnational societal spaces': Ludger Pries, 'Transnational Societal Spaces: Which Units of Analysis, Reference and Measurement?', in Rethinking Transnationalism: The MesoLink of Organizations, ed. by Ludger Pries (London and New York: Routledge, 2008), pp. 120. On '“intermediary organizations":' Dominik Lachenmeier, 'Organizational Communication of Intermediaries in Flux: An Analytical Framework', in Protest Beyond Borders: Contentious Politics in Europe since 1945, ed. by Hara Kouki and Eduardo Romanos (New York: Berghahn Books, 2011), pp. 158-74 (p. 158). On the spatial dimensions of transnational history: Antje Dietze and Katja Naumann, 'Revising Transnational Actors from a Spatial Perspective', European Review of History, 25. 3-4 (2018), 415-30; Ángel Alcalde, 'Spatializing Transnational History: European Spaces and Territories', European Review of History, 25. 3-4 (2018), 553-67

${ }^{30}$ Saunier makes this general point about transnational relations. Saunier, Transnational History, p. 80. 
31 This was the case with bacteriology in Britain. See: Michael Worboys, Spreading Germs: Disease Theories and Medical Practice in Britain, 1865-1900 (Cambridge: Cambridge University Press, 2000). 